\title{
INCIDENCE OF PULMONARY EMBOLISM IN PATIENTS WITH NEWLY \\ DIAGNOSED COLORECTAL CANCER
}

Short Running Head:

Incidence of PE in Colorectal Cancer

MrEric S. Daniel MBBS FRACS

Colorectal Unit, Western Hospital

Melbourne, Australia

Dr Anastasia E. Dean MBBS

Colorectal Unit, Western Hospital

Melbourne, Australia

Dr Mingjoe Lim MBBS FRANZCR

Radiology Department, Western Hospital

Melbourne, Australia

Dr Mobin Master MBBS FRANZCR

Radiology Department, Western Hospital

Melbourne, Australia

A/Prof Peter Gibbs MBBS FRACP

Oncology Unit, Royal Melbourne Hospital

Melbourne, Australia

Mr Ian Faragher MBBS FRACS

This is the author manuscript accepted for publication and has undergone full peer review but has not been through the copyediting, typesetting, pagination and proofreading process, which may lead to differences between this version and the Version of Record. Please cite this article as doi: 10.1111/ans.13789

This article is protected by copyright. All rights reserved. 
Colorectal Unit, Western Hospital

Melbourne, Australia

Corresponding Author

Eric S. Daniel

Colorectal Unit

160 Gordon Street, Footscray

Melbourne, Victoria 3011

Australia

ericdaniel82@gmail.com

Ph: +61383456666

Fax: +61383456355

Disclaimers: None

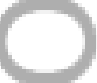

Word Count Text: 2,031

Abstract word count: 238

Tables: 3

Figure: 1

This article is protected by copyright. All rights reserved. 


\section{Abstract}

Aim: Studies have suggested a benefit from extended venous

thromboprophylaxis post-operatively in colorectal cancer with an assumed base rate of zero venous thromboembolic events prior to treatment. We aim to establish the incidence of pulmonary embolism in patients with newly diagnosed Stage III or IV colorectal cancer prior to any treatment.

Method: Consecutive patients presenting to a single health service with a new diagnosis of stage III or IV colorectal cancer were identified from a prospective database, for the period between January 2011 and September 2014.

Contemporaneous clinical data was reviewed. Included patients had a computerized tomography chest scan for pre-operative staging for cancer. The diagnosis of pulmonary emboli was made on chest computerized tomograph.

Results: Of 330 patients identified 224 had baseline computerized tomography chest imaging available for review, of which 107 (47.8\%) were technically adequate scans. Pulmonary emboli were identified on five (4.7\%) of these 107 , including one of five patients (1.7\%) with Stage III and four of five patients (8.3\%) with stage IV disease.

This article is protected by copyright. All rights reserved. 
None of the 107 patients with adequate scans had postoperative pulmonary emboli or deep vein thrombosis.

Conclusion: There is a clinically significant baseline rate of asymptomatic pulmonary emboli in patients with stage III and IV colorectal cancer that can be demonstrated on the staging chest computerized tomography scan. Pulmonary emboli described as a postoperative event in previous series may have been present prior to surgery.

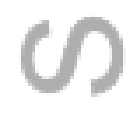

Keywords: pulmonary embolism, colorectal cancer

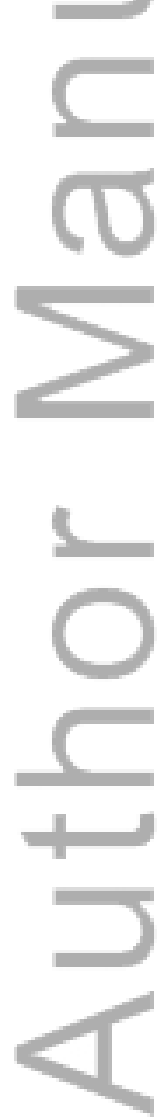

This article is protected by copyright. All rights reserved. 


\section{Introduction}

The relationship between venous thromboembolism (VTE) and malignancy is well established; it forms a significant cause of morbidity and mortality in patients with cancer ${ }^{1}$. For patients with colorectal cancer VTE is a major cause of mortality and morbidity with a reported rate of thromboembolism of $5.0 \%$ in the first 6 months from diagnosis ${ }^{2,3}$. The risk of VTE has been established in the neoadjuvant period $^{4-6}$, perioperative period ${ }^{7,8}$ and in patients with metastatic disease ${ }^{9,10}$.

Standard practice in the pre-operative assessment of colorectal adenocarcinoma now includes the use of computed tomography (CT) of the chest, abdomen and pelvis to assess for distant disease ${ }^{11,12}$. Where metastatic disease is detected this may impact on multi-disciplinary management. Incidental findings on CT imaging are not uncommon, and include detection of asymptomatic pulmonary emboli (PE) on staging chest CT. To our knowledge the frequency and significance of this finding has not previously been reported.

We conducted a review of a consecutive series of patients with Stage III and IV colorectal adenocarcinoma to establish the adequacy of initial imaging for detection of PE and the incidence of PE. The clinical course of any patient with 
PE was reviewed. A search of our database was also conducted to determine the incidence of postoperative PE.

\section{Materials and Methods}

We queried the BioGrid database ${ }^{13}$ utilized by Western Health to identify patients with colorectal cancer between January 2011 and September 2014. For our analyses we included all patients diagnosed with Stage III or IV colorectal adenocarcinoma $^{14}$. We reviewed their medical record data and staging CT scans. Exclusion criteria were patients that did not have a CT chest prior to treatment $(n=106)$, original images not being available for review $(n=0)$, a prior history of $\operatorname{VTE}(\mathrm{n}=0)$ or documented thrombophilia $(\mathrm{n}=0)$.

All CT chests were reviewed separately by two radiologists (ML and MM). A positive study was defined as evidence of PE. We defined negative studies as scans having no evidence of PE and at least 250HU (Hounsfield unit) of contrast enhancement in the pulmonary trunk ${ }^{15}$. CT studies with less than $250 \mathrm{HU}$ in the pulmonary trunk were defined as non-diagnostic for PE, that is it was insufficient contrast enhancement to adequately exclude a PE. These studies were excluded from the main analysis.

This article is protected by copyright. All rights reserved. 
Our standardized staging scanning protocol included intravenous contrast of $100 \mathrm{ml}$ Omnipaque 350 at $3 \mathrm{ml} / \mathrm{sec}$ via 20 - or 22 -gauge cannula. The chest scan was performed during the arterial phase from above the lung apices to the below the costophrenic angles. The abdominal / pelvis scan was performed during the portal venous phase from above the diaphragm to the symphysis pubis. Chest and abdominal / pelvis soft-tissue images were reconstructed with $0.6 \mathrm{~mm}$ thickness and spacing; chest lung window images were reconstructed with $5 \mathrm{~mm}$ thickness and spacing.

A search of our prospective database was conducted to define the frequency of 30-day post-operative PE in all stage III and IV patients with available imaging.

Data calculations were carried out using Microsoft Excel 2011 and GraphPad Software, Inc. http://www.graphpad.com/quickcalc/ (accessed 6/6/2015). Comparison was made between patients with Stage III and IV disease; statistical analyses comparing age and contrast enhancement (HU) was calculated using a t-test. Analysis comparing gender was calculated using a chi-squared test; whilst analysis comparing incidence of pulmonary embolus was calculated using a Fisher exact test. Proportions of incidence of PE had 95\% confidence intervals calculated using the Clopper and Pearson method.

Ethical and institutional approval was gained from the Western Health Low Risk 
Human Research Ethics Panel.

\section{Results}

There were 330 patients that had Stage III or IV colorectal adenocarcinoma diagnosed between January 2011 and September 2014. Of this cohort 224 had a CT chest prior to any form of treatment that was available for review. Of these studies 117 (52.2\%) were considered non-diagnostic due to insufficient contrast enhancement (Figure 1). Five of 107 ((4.7\%) 95\% CI 0.0153 - 0.1057) studies were positive for PE, including 1 of 59 cases with stage III and 4 of 48 cases with stage IV disease (Table 1).

Of the five cases with PE on pre-treatment imaging (5/107), four had been documented in the initial CT report, and three received anticoagulation with enoxaparin (Table 2). A patient with a main pulmonary artery PE was the only symptomatic patient. One case with a sub-segmental PE did not receive therapeutic anticoagulation as this was deemed not clinically significant. In the one patient where a segmental PE on the initial CT chest was not reported; they became symptomatic postoperatively with a lobar PE formally diagnosed on CT chest approximately 2 months post the original study and was also treated with enoxaparin.

This article is protected by copyright. All rights reserved. 
Two patients proceeded to surgery post diagnosis of PE and treatment; standard perioperative anticoagulation was given with a prophylactic dose of enoxaparin at induction, compression stockings and sequential compression devices. The therapeutic dose was given the day prior and restarted the day post operation. There was no documented post-operative bleeding in these 2 cases.

There were no new cases of pulmonary emboli in the 107 patients included in our study, within 30 days of surgery. Two patients with non-diagnostic studies (2/117) had PE diagnosed within 30 days of surgery on chest CT. No new deep vein thrombosis (DVT) occurred in either group (0/330) on review of medical records within 30 days of surgery; however our database did not include the total number of patients that had postoperative imaging for suspicion of DVT or PE but only those that had positive studies.

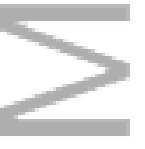

There were no risk factors for VTE in the patients with PE, as well as no history of surgery or admission in the previous 30 days, chemotherapy, prior thromboembolic events or documented thrombophilia. Of the four patients with stage IV disease, three patients had extensive lymphadenopathy, two had hepatic metastases and one extensive pulmonary metastases.

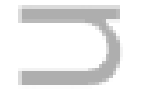

\section{Discussion}

This article is protected by copyright. All rights reserved. 
Thromboembolic disease is a potentially significant complication of colorectal cancer, with the risk increased in patients with stage IV disease ${ }^{9,10}$ and in the postoperative period $^{7,8}$. Pulmonary emboli may be diagnosed following a symptomatic presentation, or as an incidental finding on imaging for staging or other purposes. Our study has established that a significant number of patients have non-diagnostic preoperative imaging for the purposes of detecting asymptomatic PE, and that where scans are adequate the incidence of PE is significant; $4.7 \%$ (95\% CI $0.0153-0.1057)$. Our data is important as asymptomatic PE do have potential clinical consequences ${ }^{16}$. Also a significant rate of $\mathrm{PE}$ at diagnosis could significantly confound any analysis of the rate of postoperative VTE, including in randomized intervention studies where there is an assumption of a base rate of zero PE.

To our knowledge prior studies of the incidence of VTE post-operatively have not examined for the presence of PE at the time of initial diagnosis. This is partly because CT chest imaging at baseline has only become standard practice in recent years. For example, in a survey of clinical practice at multiple Australian sites in 2009, 222 of 257 (86.4\%) patients had an abdominal CT at baseline and only $95(40.0 \%)$ a chest CT. Importantly this study also demonstrated the impact of baseline CT chest imaging, with a third of cases with suspicious findings resulted in further investigation or a change in management ${ }^{17}$. 
Previous studies include an epidemiological study concerning VTE in multiple malignancies, which reported a concurrent rate of $0.2 \%$ and $0.6 \%$ in colorectal cancer patients with regional and remote disease respectively. Concurrent was defined as a diagnosis of VTE during the hospitalisation of when the cancer was diagnosed. The location of VTE, time of diagnosis and modality of investigation was determined by hospital coding ${ }^{18}$. The authors did not specify whether VTE was confirmed prior to any treatment or make any further comment upon the specific location of VTE. Chandra et al recorded symptomatic VTE post colorectal surgery at a rate of $0.79 \%$ as an inpatient and $0.39 \%$ at 30 days of which all were $\mathrm{PE}^{19}$. Holwell et al reported an incidence of $4.1 \%$ at 90 days of which 6 out of 8 patients had $\mathrm{PE}^{20}$. A large epidemiological study reported the incidence of VTE in colorectal adenocarcinoma as 5.0\% in the first six months after diagnosis. The authors did not specify the timing of diagnosis of VTE ${ }^{21}$.

A meta-analysis ${ }^{22}$ and four randomized control trials have concluded a statistically significant reduction in risk of VTE with extended DVT prophylaxis post operatively for abdominal and pelvic surgery for cancer. All randomized controlled trials (Table 3) included both asymptomatic and symptomatic DVT confirmed on venography or sonography. CT chest or ventilation / perfusion lung scintigraphy was only performed for investigation of patients with suspected $\mathrm{PE}^{7,23-25}$. Vedovati et $\mathrm{al}^{23}$ examined patients specifically who had undergone laparoscopic colorectal surgery. 
In these series often small absolute differences are observed between the study groups, differences that may in part be due to imbalances between study arms due to pre-existing PE (Table 3). Given this we would strongly recommend that any prospective study exploring any type of extended VTE prophylaxis should mandate adequate imaging on all patients at diagnosis as an eligibility criteria, with any patient with PE at diagnosis to be excluded from the study.

Strengths of our study include that this is a consecutive series of patients from a single institution and comprehensive prospective data collection, including documentation of VTE. All images were reviewed by two radiologists that were blinded to the original study report and clinical data, and that quality assurance of imaging was performed prior to including images in our series. The limitations of our study are: the modest number of patients meant we could not do a formal statistical comparison of PE incidence for Stage III or IV disease; we did not examine any patients with stage I or II disease, where the rate of incidental PE may be lower; and, we did not have the pre-operative incidence of DVT. Furthermore given the number of non-diagnostic CT chest scans we may be underestimating the incidence of pretreatment PE.

There is a significant baseline incidence of PE in patients with stage III or IV colorectal cancer that has not been recognized in previous studies. A substantial 
proportion of these may be missed due to non-diagnostic imaging, so we would recommend the initial CT chest component of the staging scan be timed by the technician with adequate contrast enhancement of both the pulmonary and systemic circulation to allow for the diagnosis or exclusion of PE. Any future prospective studies of thromboembolic disease should include baseline imaging with adequate contrast to document the true incidence of postoperative VTE.

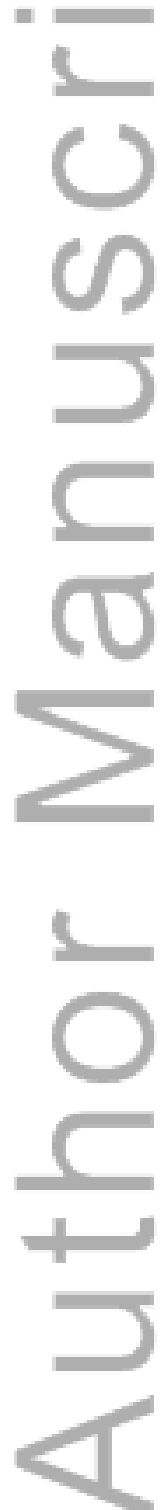

This article is protected by copyright. All rights reserved. 


\section{Acknowledgements}

The authors thank the surgeons of the Colorectal and General Surgery Unit, Western Health; staff of the Radiology Department, Western Health; members of the Colorectal Unit multidisciplinary team, and Michael Harold, the project manager for the BioGrid database. The project could not have been completed without their assistance.

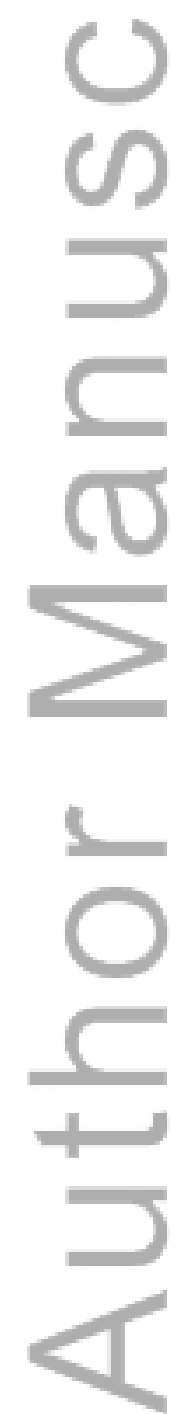

This article is protected by copyright. All rights reserved. 


\section{Disclosures}

The authors have no conflicts of interest to declare.

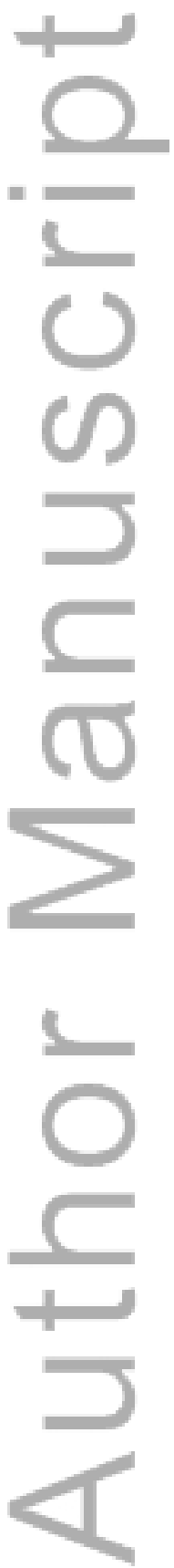

This article is protected by copyright. All rights reserved. 


\section{References}

1. Imberti D, Agnelli G, Ageno W, et al. Clinical characteristics and management of cancer-associated acute venous thromboembolism: findings from the MASTER Registry. Haematologica. 2008 Feb;93(2):2738.

2. Alcalay A, Wun T, Khatri V, et al. Venous thromboembolism in patients with colorectal cancer: incidence and effect on survival. Journal of Clinical $=$ Oncology. 2006 Feb 28;24(7):1112-8.

3. Khorana AA, Francis CW, Culakova E, Kuderer NM, Lyman GH. Thromboembolism is a leading cause of death in cancer patients receiving outpatient chemotherapy. J Thromb Haemost. 2007 Mar;5(3):632-4.

4. Ngan SY, Burmeister B, Fisher RJ, et al. Randomized trial of short-course radiotherapy versus long-course chemoradiation comparing rates of local recurrence in patients with T3 rectal cancer: Trans-Tasman Radiation Oncology Group trial 01.04. Journal of Clinical Oncology. 2012 Oct 31;30(31):3827-33.

5. Chua YJ, Barbachano Y, Cunningham D, Oates JR. Neoadjuvant capecitabine and oxaliplatin before chemoradiotherapy and total mesorectal excision in MRI-defined poor-risk rectal cancer: a phase 2 trial. Lancet Oncol. 2010.

6. Rödel C, Liersch T, Becker H, et al. Preoperative chemoradiotherapy and postoperative chemotherapy with fluorouracil and oxaliplatin versus fluorouracil alone in locally advanced rectal cancer: initial results of the German CAO/ARO/AIO-04 randomised phase 3 trial. Lancet Oncology. 2012 Jun 30;13(7):679-87.

7. Kakkar VV, Balibrea JL, Martínez-González J, Prandoni P, CANBESURE Study Group. Extended prophylaxis with bemiparin for the prevention of venous thromboembolism after abdominal or pelvic surgery for cancer: the CANBESURE randomized study. J Thromb Haemost. Blackwell Publishing Ltd; 2010 Jun;8(6):1223-9.

8. Akl EA, Labedi N, Terrenato I, et al. Low molecular weight heparin versus unfractionated heparin for perioperative thromboprophylaxis in patients with cancer. Cochrane Database Syst Rev. 2011;(11):CD009447.

9. Wun T, Wun T, White RH. Venous thromboembolism (VTE) in patients with cancer: epidemiology and risk factors. Cancer Invest. 2009;27 Suppl 
$1(\mathrm{~s} 1): 63-74$.

10. Blom JW, Vanderschoot JPM, Oostindiër MJ, et al. Incidence of venous thrombosis in a large cohort of 66,329 cancer patients: results of a record linkage study. J Thromb Haemost. 2006 Mar;4(3):529-35.

11. National Institute for Health and Care Excellence. Colorectal: The diagnosis and management of colorectal cancer [Internet]. 2015. 50 p. Available from: guidance.nice.org.uk/cg131

12. National Comprehensive Cancer Network. NCCN Clinical Practice

$=$ Guidelines in Oncology: Colon Cancer. V 2.2015 [Internet]. 2014. 143 p. Available from: www.nccn.org

13. Merriel RB, Gibbs P, O'Brien TJ, Hibbert M. BioGrid Australia facilitates collaborative medical and bioinformatics research across hospitals and medical research institutes by linking data from diverse disease and data types. Lindblom A, Robinson PN, editors. Hum Mutat. 2011 May;32(5):517-25.

14. Edge SB. AJCC Cancer Staging Handbook. Springer Verlag; 2010. 1 p.

15. Effect of Patient Weight and Scanning Duration on Contrast Enhancement during Pulmonary Multidetector CT Angiography1. Radiological Society of North America; 2007 Feb 1;242(2):582-9. Available from: http://pubs.rsna.org/doi/abs/10.1148/radiol.2422052132

16. Dentali F, Ageno W, Pierfranceschi MG, et al. Prognostic relevance of an asymptomatic venous thromboembolism in patients with cancer. J Thromb Haemost. Blackwell Publishing Ltd; 2011 May;9(5):1081-3.

17. Kosmider S, Stella DL, Field K, et al. Preoperative investigations for metastatic staging of colon and rectal cancer across multiple centres--what is current practice? Colorectal Dis. Blackwell Publishing Ltd; 2009 Jul;11(6):592-600.

18. Chew HK, Wun T, Harvey D, Zhou H, White RH. Incidence of venous thromboembolism and its effect on survival among patients with common cancers. Arch Intern Med. 2006 Feb 27;166(4):458-64.

19. Chandra R, Melino G, Thomas M, et al. Is extended thromboprophylaxis necessary in elective colorectal cancer surgery? ANZ J Surg. Royal Australasian College of Surgeons (RACS); 2013 Dec;83(12):968-72.

20. Holwell A, McKenzie J-L, Holmes M, et al. Venous thromboembolism prevention in patients undergoing colorectal surgery for cancer. ANZ J 
Surg. 2014 Apr;84(4):284-8.

21. Alcalay A, Wun T, Khatri V, et al. Venous thromboembolism in patients with colorectal cancer: incidence and effect on survival. J Clin Oncol. 2006 Mar 1;24(7):1112-8.

22. Rasmussen MS, Jørgensen LN, Wille-Jørgensen P. Prolonged thromboprophylaxis with low molecular weight heparin for abdominal or pelvic surgery. Rasmussen MS, editor. Cochrane Database Syst Rev. Chichester, UK: John Wiley \& Sons, Ltd; 2009;(1):CD004318.

23. Vedovati MC, Becattini C, Rondelli F, et al. A randomized study on 1-week versus 4-week prophylaxis for venous thromboembolism after laparoscopic surgery for colorectal cancer. Annals of Surgery. 2014 Apr;259(4):665-9.

24. Rasmussen MS, Jorgensen LN, Wille-Jørgensen P, et al. Prolonged prophylaxis with dalteparin to prevent late thromboembolic complications in patients undergoing major abdominal surgery: a multicenter randomized open-label study. J Thromb Haemost. 2006 Nov;4(11):238490.

25. Bergqvist D, Agnelli G, Cohen AT, et al. Duration of prophylaxis against venous thromboembolism with enoxaparin after surgery for cancer. N Engl J Med. 2002 Mar 28;346(13):975-80. 
Table 1 - Patient characteristics

\begin{tabular}{|c|c|c|c|}
\hline & \multicolumn{2}{|c|}{ Total adequate $n=107(32.4 \%)$} & \\
\hline AJCC stage & III $n=59$ & $\mathrm{IV} \mathrm{n}=48$ & P value \\
\hline Median age (range) & $68(46-87)$ & $70(30-93)$ & $0.644^{*}$ \\
\hline Sex & $\begin{array}{l}\text { F } 33(55.9 \%) \\
\text { M } 26(44.1 \%)\end{array}$ & $\begin{array}{l}\text { F } 26(54.2 \%) \\
\text { M } 22(45.8 \%)\end{array}$ & $0.855^{* *}$ \\
\hline $\begin{array}{l}\text { Mean pulmonary } \\
\text { contrast } \\
\text { enhancement }\end{array}$ & $322 \mathrm{HU}$ & $317 \mathrm{HU}$ & $0.685^{*}$ \\
\hline \multirow[t]{2}{*}{ PE on CT Chest } & $\begin{array}{l}1(1.7 \%) \\
95 \% \text { CI } 0.0004- \\
0.0909 \\
\end{array}$ & $\begin{array}{l}4(8.3 \%) \\
95 \% \text { CI } 0.0232- \\
0.1998 \\
\end{array}$ & $0.171^{* * *}$ \\
\hline & \multicolumn{2}{|c|}{$5(4.7 \%) 95 \%$ CI $0.0153-0.1057$} & \\
\hline
\end{tabular}

* Calculated with t-test

** Chi-square test

*** Fisher exact test

PE - pulmonary embolus

$\mathrm{CT}$ - computerized tomography

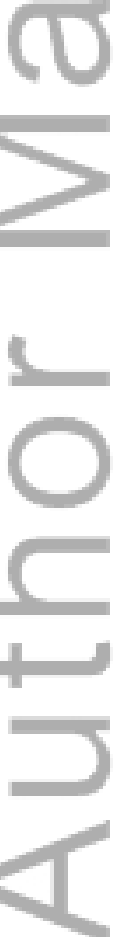

This article is protected by copyright. All rights reserved. 
Table 2 - PE confirmed patients

\begin{tabular}{|l|l|l|l|l|l|}
\hline Age & Gender & $\begin{array}{l}\text { Tumour } \\
\text { location }\end{array}$ & $\begin{array}{l}\text { AJCC } \\
\text { Stage }\end{array}$ & CT findings & $\begin{array}{l}\text { Contrast } \\
\text { enhancement }\end{array}$ \\
\hline 69 & F & Sigmoid & III & Lobar PE & $300 \mathrm{HU}$ \\
\hline 56 & F & Caecum & IV & Segmental PEs & 204HU \\
\hline 58 & F & $\begin{array}{l}\text { Ascending } \\
\text { colon }\end{array}$ & IV & Subsegmental PEs & $327 \mathrm{HU}$ \\
\hline 68 & F & Caecum & IV & $\begin{array}{l}\text { Main pulmonary } \\
\text { artery PE }\end{array}$ & 295HU \\
\hline 69 & F & Caecum & IV & Segmental PE & 450HU \\
\hline
\end{tabular}

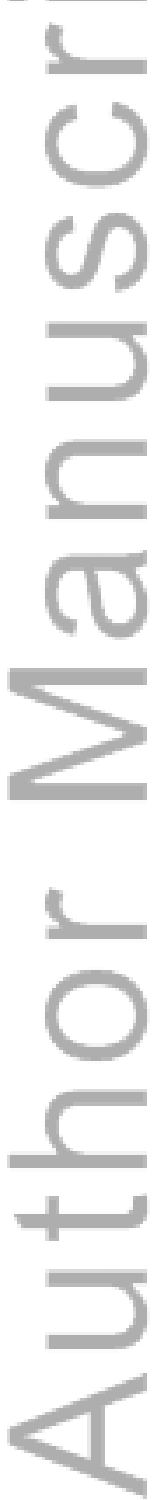

This article is protected by copyright. All rights reserved. 
Table 3 - Summary of randomized control trials

\begin{tabular}{|c|c|c|c|c|c|}
\hline $\begin{array}{l}\text { Author } \\
\text { (Year) }\end{array}$ & $\begin{array}{l}\text { Study } \\
\text { design }\end{array}$ & Patients & Intervention & $\begin{array}{l}\text { Primary } \\
\text { outcome }\end{array}$ & Result \\
\hline $\begin{array}{l}\text { Bergqvist } \\
\text { et al (2002) }\end{array}$ & $\begin{array}{l}\text { Double- } \\
\text { blinded }\end{array}$ & 332 & $\begin{array}{l}\text { LWMH ( } 21 \text { days on } \\
\text { discharge) vs } \\
\text { placebo (LWMH as } \\
\text { inpatient only) }\end{array}$ & $\begin{array}{l}\text { Incidence of } \\
\text { VTE (day } 25 \text { - } \\
\text { 31) }\end{array}$ & $\begin{array}{l}8(4.8 \%) \text { LWMH vs } \\
20(12.0 \%) \text { placebo } \\
(\mathrm{P}=0.02)\end{array}$ \\
\hline $\begin{array}{l}\text { Rasmu } \\
\text { et al (2 }\end{array}$ & $\begin{array}{l}\text { Assessor } \\
\text {-blinded }\end{array}$ & 427 & $\begin{array}{l}\text { Extended LWMH } \\
\text { ( } 28 \text { days) vs short- } \\
\text { term LWMH ( } 7 \\
\text { days) }\end{array}$ & $\begin{array}{l}\text { Incidence of } \\
\text { VTE (day } 7 \text { - } \\
\text { 28) }\end{array}$ & $\begin{array}{l}29(7.3 \%) \text { extended } \\
\text { LWMH vs } 12 \\
(16.3 \%) \text { short-term } \\
\text { LWMH }(P=0.012)\end{array}$ \\
\hline $\begin{array}{l}\text { Kakkar et al } \\
(2010)\end{array}$ & $\begin{array}{l}\text { Double- } \\
\text { blinded }\end{array}$ & 488 & $\begin{array}{l}\text { Bemiparin ( } 28 \\
\text { days) vs bemiparin } \\
\text { ( } 8 \text { days) and } \\
\text { placebo }\end{array}$ & $\begin{array}{l}\text { Composite of } \\
\text { DVT, non- } \\
\text { fatal PE and } \\
\text { all-cause } \\
\text { mortality at } \\
\text { day } 28\end{array}$ & $\begin{array}{l}25(10.1 \%) \\
\text { bemiparin vs } 32 \\
(13.3 \%) \text { placebo }(\mathrm{P}= \\
0.26) \\
\text { †TE } 2(0.8 \%) \\
\text { bemiparin vs } 11 \\
(4.6 \%) \text { placebo }(\mathrm{P}= \\
0.010)\end{array}$ \\
\hline $\begin{array}{l}\text { Vedovati et } \\
\text { al (2014) }\end{array}$ & $\begin{array}{l}\text { Assessor } \\
\text {-blinded }\end{array}$ & 225 & $\begin{array}{l}\text { Extended heparin } \\
\text { (28+/- } 2 \text { days) vs } \\
\text { short heparin }(8 \\
+/ \text { - days })\end{array}$ & $\begin{array}{l}\text { Symptomatic } \\
\text { or U/S } \\
\text { detected VTE } \\
\text { at day } 28+/- \\
2\end{array}$ & $\begin{array}{l}0(0 \%) \text { extended } \\
\text { heparin vs } 11(9.7 \%) \\
\text { short heparin }(\mathrm{P}= \\
0.001) \text { at } 28+-2 \\
\text { days }\end{array}$ \\
\hline
\end{tabular}

LWMH - low molecular weight heparin

VTE-venous thromboembolism

DVT - deep venous thrombosis

PE - pulmonary embolus

† Incidence of major venous thromboembolism was not the primary outcome

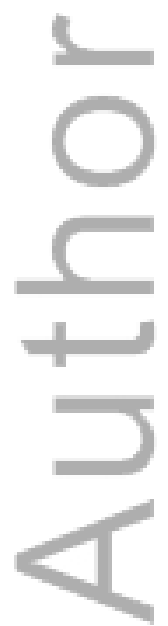

This article is protected by copyright. All rights reserved. 


\section{University Library}

\section{- M M N E R VA A gateway to Melbourne's research publications}

Minerva Access is the Institutional Repository of The University of Melbourne

Author/s:

Daniel, ES;Dean, AE;Lim, M;Master, M;Gibbs, P;Faragher, I

Title:

Incidence of pulmonary embolism in patients with newly diagnosed colorectal cancer

Date:

2018-04-01

Citation:

Daniel, E. S., Dean, A. E., Lim, M., Master, M., Gibbs, P. \& Faragher, I. (2018). Incidence of pulmonary embolism in patients with newly diagnosed colorectal cancer. ANZ JOURNAL OF SURGERY, 88 (4), pp.E228-E231. https://doi.org/10.1111/ans.13789.

Persistent Link:

http://hdl.handle.net/11343/291827 